\title{
Article \\ Evaluation and Characterization of Alginate Extracted from Brown Seaweed Collected in the Red Sea
}

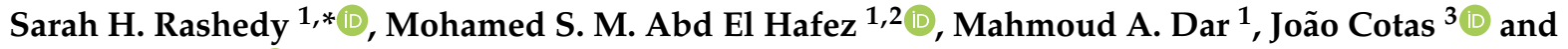 \\ Leonel Pereira ${ }^{3}$ (D) \\ 1 National Institute of Oceanography and Fisheries (NIOF), Cairo 11516, Egypt; \\ mohamedsaid80@yahoo.com (M.S.M.A.E.H.); mahmoud_rady@yahoo.com (M.A.D.) \\ 2 City of Scientific Research and Technological Applications, SRTA-City, New Borg El-Arab City 21934, Egypt \\ 3 Marine and Environmental Sciences Centre (MARE), Department of Life Sciences, University of Coimbra, \\ 3000-456 Coimbra, Portugal; jcotas@uc.pt (J.C.); leonel@bot.uc.pt (L.P.) \\ * Correspondence: sarahamdy.niof@gmail.com; Tel.: +02-010-2586-5156
}

check for updates

Citation: Rashedy, S.H.; Abd El Hafez, M.S.M.; Dar, M.A.; Cotas, J.;

Pereira, L. Evaluation and

Characterization of Alginate

Extracted from Brown Seaweed Collected in the Red Sea. Appl. Sci. 2021, 11, 6290. https://doi.org/ 10.3390/app11146290

Academic Editor:

Anabela Raymundo

Received: 24 June 2021

Accepted: 5 July 2021

Published: 7 July 2021

Publisher's Note: MDPI stays neutral with regard to jurisdictional claims in published maps and institutional affiliations.

Copyright: (c) 2021 by the authors. Licensee MDPI, Basel, Switzerland. This article is an open access article distributed under the terms and conditions of the Creative Commons Attribution (CC BY) license (https:/ / creativecommons.org/licenses/by/ $4.0 /)$.

\begin{abstract}
Alginates are one of the most important compounds of brown seaweeds. These compounds are employed in the food area, because of their important rheological properties, such as viscosity, gelling, and stabilizing features and as dietary fiber source. In this study, five species of dominant brown seaweeds were collected in the Red Sea (Padina boergesenii, Turbinaria triquetra, Hormophysa cuneiformis, Dictyota ciliolata, and Sargassum aquifolium) so as to characterize the alginate yield and its properties. The analysis demonstrated differences in the alginate yield among the seaweeds. The highest yield of alginate was recorded in the species T. triquetra $(22.2 \pm 0.56 \% \mathrm{DW})$, while the lowest content was observed in H. cuneiformis $(13.3 \pm 0.52 \% \mathrm{DW})$. The viscosity from the alginates varied greatly between the species, whereas the $\mathrm{pH}$ varied slightly. The alginate exhibited a moisture content between 6.4 and $13.1 \%$, the ash content ranged between 12.3 and $20 \%$ DW, the protein reached values from 0.57 to $1.47 \% \mathrm{DW}$, and the lipid concentration varied from 0.3 to $3.5 \% \mathrm{DW}$. Thus, the phytochemical analysis demonstrated that the extracted alginates can be safely applied in the food industry. Furthermore, the alginate yield reveals the potential application of these seaweeds as a nutraceutical raw source, which can be exploited by the food industry.
\end{abstract}

Keywords: alginate; dietary fiber; Red Sea; physicochemical properties; phytochemical properties; nutritional

\section{Introduction}

Polysaccharides are one of the most important and exploited seaweed compounds in the food industry and by nutraceutical companies. These compounds are being used as natural additives in food, to enhance food quality, and as ingredients, to add nutritional value, namely for the dietary fiber content [1,2]. Moreover, when polysaccharides are ingested, they absorb water in the human digestive tract, increasing the satiety feeling, consequently reducing the caloric intake. Hereupon, seaweed polysaccharides prevent and reduce diverse diseases' incidence, such as obesity and obesity-related diseases [3]. In addition, these polysaccharides can also modify the intestinal activity by modulating the intestine microflora, and these algal compounds have the capacity to modify the absorption rates of other nutrients. This capacity is derived from the complete or limited fermentation in the large intestine [4,5].

As seaweed polysaccharides act as a dietary fiber, they have a low caloric content $(1.4 \mathrm{Kcal} / \mathrm{g})$. Consequently, these compounds can be used as supplements to stabilize and modulate food consistency, such as in baked food, jams, ice cream, jellies, and mayonnaise [6-11]. Regarding the algal polysaccharide biotechnological applications that directly affect humans, especially in biomedical and food areas, the purity of the polysaccharide is a determining factor in order to guarantee the compound's safety in order to be used in 
food processing. This safety record is mainly determined by analyzing its phytochemical properties and protein content (purity rate or polysaccharide quality level) [12,13]. If the polysaccharide purity rate is high, these polysaccharides show interesting rheological properties [14], as well as biodegradability, biocompatibility, and the absence of toxicity [6]. If the polysaccharide demonstrates a high rate of impurities, it can have adverse effects on human health, and their application in the food, pharmaceutical, and biomedical areas is not recommended [15]. This is very explicit and restrictive by the authorities from Europe and United States of America so as to guarantee a safe human intake with low adverse effects [16,17]. The low adverse effects are mainly the results of an overdosage of a specific nutrient, and the excessive dietary fiber ingestion results in soft stools or diarrhea symptomatology $[18,19]$. Alginate, the main polysaccharide synthesized by brown seaweeds, is one of the most exploited polysaccharides in the food industry, because of its inherent and excellent properties as a thickener and stabilizer agent in processed foods [2]. It presents positive features for the food industry, such as being low cost, easy to incorporate into food, being well accepted for human food consumption, and quick to adapt for a specific role $[2,20]$.

Alginic acid is the main structural polysaccharide present in the cell wall and in the intercellular matrix of brown seaweed, providing flexibility and mechanical resistance to the force of the water in the marine environment where the seaweed grows [21]. Alginic acid is a complex organic compound composed of monomers of d-mannuronic acid and 1 -guluronic acid. So, alginate is composed of 1, 4- $\beta$-d-mannuronic acid (M) and 1, 4- $\alpha-1$ guluronic acid $(\mathrm{G})$ monomers, with a homogeneous (Poly-M and Poly-G) or heterogeneous (MG) block configuration. The extraction process is based on the conversion of an insoluble mixture of salts of alginic acid into a soluble salt (alginate), which is suitable for water extraction $[2,22,23]$. The proportion of the three kinds of blocks, namely GG, MM, and $\mathrm{MG}$, defines the physical features of alginates, with alginates with a high proportion of $\mathrm{M}$ blocks having a higher viscosity, while those with a high proportion of $\mathrm{G}$ blocks having higher gelling properties $[2,24]$. Alginates vary in composition among species, from 20 to $60 \%$ dry matter, and occur mainly as gels comprising magnesium, calcium, sodium, and barium ions [25]. ${ }^{1} \mathrm{H}-\mathrm{NMR}$ and FTIR techniques are the main techniques applied in the examination of alginates' composition and structural patterns [2,24].

Nowadays, alginate is one of the most exploited seaweed polysaccharides by various types of industry, and thus it is important to find and analyze new raw sources to extract alginate around the globe so as to meet the high demand for alginate, mainly sodium alginate [26].

Despite the existence of many studies regarding the nutritional content and antimicrobial and antioxidant activities of the Red Sea seaweeds [27-29], there is almost no information available about the quantity and quality of the alginates in the Red Sea brown seaweeds, which could be a new source of raw material to be exploited by the alginate extraction industry. In this context, this study focused on the assessment of the most dominant (high biomass available) brown seaweeds in the Red Sea, in order to analyze their alginate yield. In addition, there was a characterization of the extracted alginate to guarantee the purity rate and the possibility to be incorporated into the food industry.

\section{Materials and Methods}

\subsection{Selection and Collection of Seaweed}

Different species of brown seaweeds (Padina boergesenii Alender and Kraft, Turbinaria triquetra (J. Agardh) Kützing, Hormophysa cuneiformis (Gmelin) Silva, Dictyota ciliolata Sonder ex Kützing, and Sargassum aquifolium (Turner) C. Agardh; Figure 1) were collected in the summer of 2020 (Table 1) from the Red Sea shore at Hurghada, Egypt, from the tidal zone in front of the Marine biological station (NIOF), in an area adjacent to the frontal reef dominated by corals, which begins at about $1.5 \mathrm{~m}$ deep, with the lowest part of the reef plain being dominated by the canopy-forming algae Turbinaria triquetra, between latitude $27^{\circ} 17^{\prime} 13^{\prime \prime} \mathrm{N}$ and longitude $33^{\circ} 46^{\prime} 21^{\prime \prime} \mathrm{E}$ (Figure 2). 


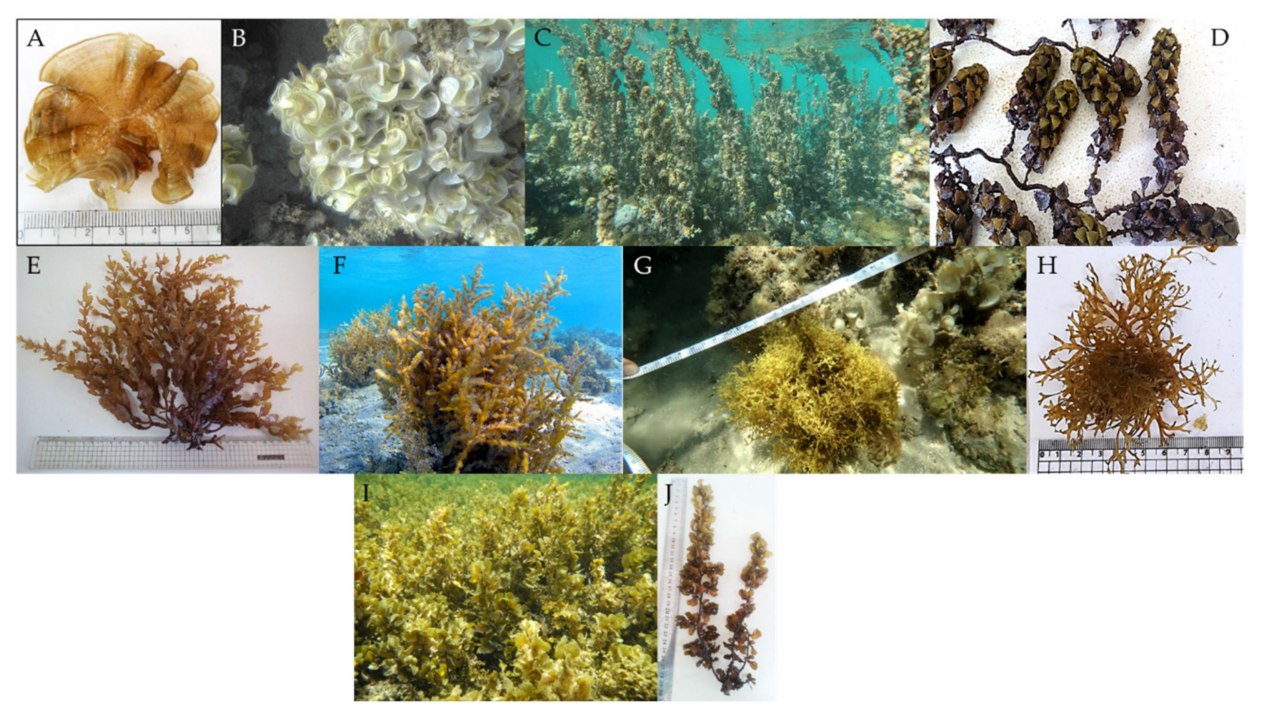

Figure 1. Seaweeds species images: Padina boergesenii: (A) whole thallus of the species and (B) view in the natural habitat at the NIOF site. Turbinaria triquetra: (C) view in the natural habitat at the NIOF site and (D) whole thallus of the species. Hormophysa cuneiformis: (E) whole thallus of the species and (F) view in the natural habitat at the NIOF site. Dictyota ciliolata (G) view in the natural habitat at the NIOF site and (H) whole thallus of the species. Sargassum aquifolium (I) view in the natural habitat at the NIOF site and (J) whole thallus of the species.

Table 1. Physiochemical characterization of the local of seaweed collection.

\begin{tabular}{ccccccc}
\hline $\begin{array}{c}\text { Water } \\
\text { Temperature }\left({ }^{\circ} \mathrm{C}\right)\end{array}$ & $\mathbf{p H}$ & Salinity (ppt) & $\begin{array}{c}\text { Dissolved } \\
\text { Oxygen }(\mathrm{mg} / \mathrm{L})\end{array}$ & $\begin{array}{c}\text { Dissolved } \\
\text { Nitrate }(\mu \mathrm{M})\end{array}$ & $\begin{array}{c}\text { Dissolved } \\
\text { Ammonium }(\mu \mathrm{M})\end{array}$ & $\begin{array}{c}\text { Dissolved Inorganic } \\
\text { Phosphate }(\mu \mathrm{M})\end{array}$ \\
\hline 30.4 & 7.9 & 42.3 & 5.3 & 1.2 & 2.3 & 0.16 \\
\hline
\end{tabular}

These species were selected according to previous studies [30-32] that confirmed that these species were dominant at the NIOF site at Hurghada, Egypt (Figure 2).

\subsection{Identification of Selected Seaweed and Preparation}

The seaweed species were identified according to their morphological characteristics with taxonomic references [33-36]. Moreover, the herbarium specimens of Prof. Islam EL-Manawy present in Marine Botany Lab, Botany Department, Faculty of Science, Suez Canal University was used. It is worthy to note that these herbaria were confirmed in 1992 in Paris at the Natural History Museum. The valid and accepted names of the seaweed species during the present study were according to the taxonomic database site created and managed by Guiry and Guiry [37].

Live and healthy seaweed specimens were harvested manually and washed thoroughly in seawater to remove epiphytes, animal castings, sand, and calcareous, as well as other adhering detritus matters. The fresh biomass was thoroughly washed again with freshwater to remove excess salt. The cleaned seaweed biomass was shade dried under an air jet to prevent photolysis and thermal degradation. The completely dried material was weighed and ground coarsely in a mechanical grinder (Herbal Grinders Mill, China) and then stored in paper sacks at $4{ }^{\circ} \mathrm{C}$ for later use. The seaweed samples were stored for two weeks at $4{ }^{\circ} \mathrm{C}$ with low humidity and in the dark, before the extraction of the alginate began. 


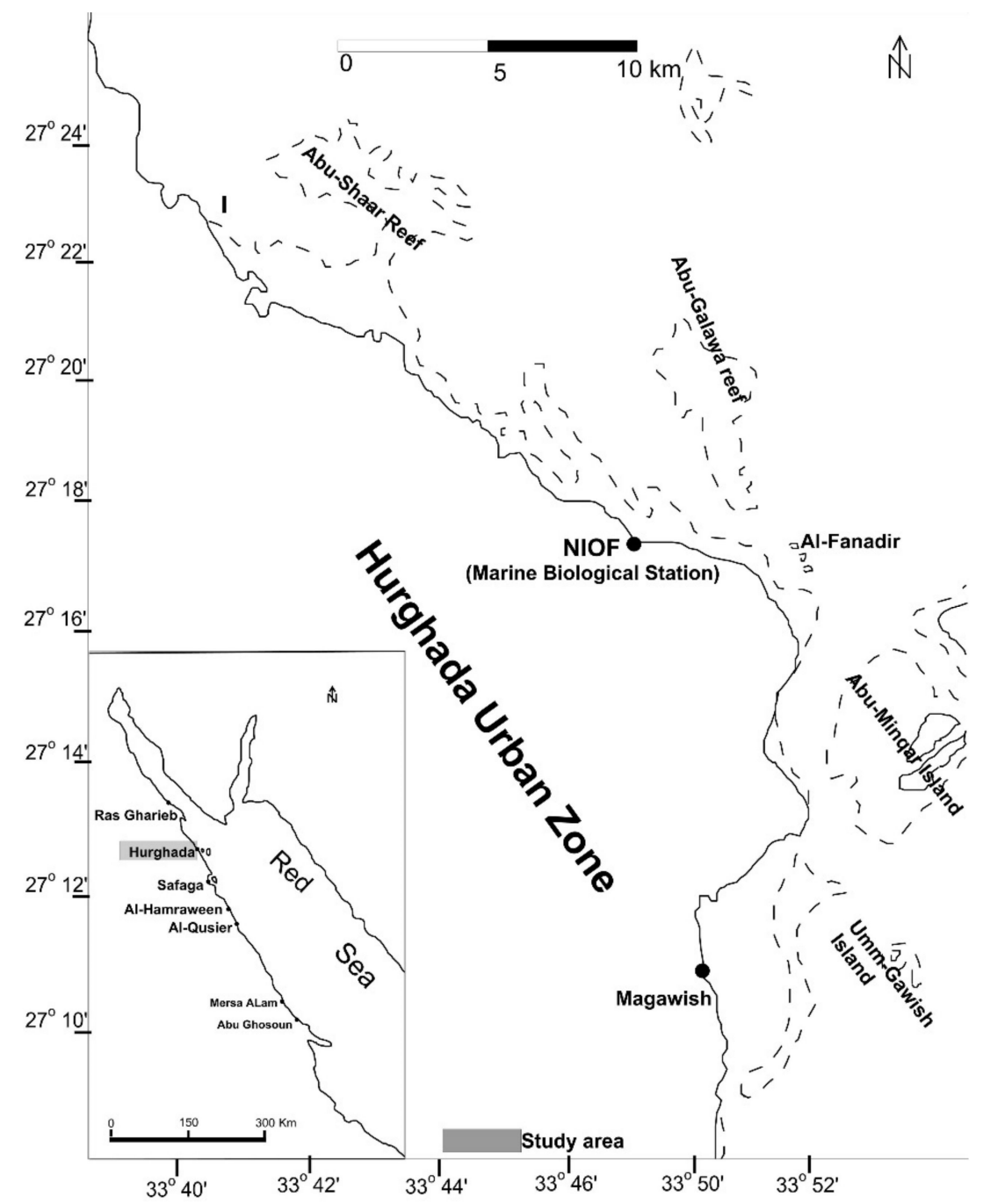

Figure 2. Samples collection site.

\subsection{Extraction of Sodium Alginate}

Sodium alginate was extracted from the selected seaweeds by the modified method based on the study of Torres et al. [38]. About $100 \mathrm{~g}$ of powdered samples were immersed in $2 \%$ formaldehyde for $24 \mathrm{~h}$, in an airtight conical flask. Then, the solution was filtered out using a Glass Funnel and Whitman qualitative filter paper $(70 \mathrm{~mm})$, while the soaked seaweeds were washed with distilled water two to three times. The $\mathrm{HCl}$ solution $(0.2 \mathrm{M})$ was added and maintained at room temperature for $24 \mathrm{~h}$. The solution was separated by filtration, and the residue was washed with distilled water two to three times. The alginate was extracted with the addition of sodium carbonate ( $2 \% \mathrm{m:v})$ to the residue previously obtained, and this process occurred overnight. Then, the extract was filtered through a gauze cloth bag and the filtrate was bleached with $2.5 \%$ (v:v) sodium hypochlorite. The extracted sodium alginate was precipitated from the solution by ethanol, then washed with acetone, and dried overnight at $60^{\circ} \mathrm{C}$. The alginate yield was measured as follows:

$$
\text { Yield of sodium alginate }(\%)=\frac{\text { Weight of alginate }}{\text { Weight of seaweed dried biomass }} * 100
$$

\subsection{Physiochemical Properties of Sodium Alginate}

\subsubsection{Estimation of $\mathrm{pH}$ and Color}

The $\mathrm{pH}$ was measured according to AOAC (Association of Official Analytical Chemists) [39]. First, $1 \mathrm{~g}$ of the extracted sodium alginate was dissolved in $100 \mathrm{~mL}$ of distilled water 
and then the $\mathrm{pH}$ was measured using a Jenway portable $\mathrm{pH}$ meter (Model 550) at room temperature. The color was evaluated by visual inspection in contrast with a white and dark illuminating background.

\subsubsection{Moisture Content}

The moisture of the alginates was determined according to AOAC [39] through the loss in mass of sodium alginate after heating at $105 \pm 1{ }^{\circ} \mathrm{C}$ for $24 \mathrm{~h}$.

\subsubsection{Estimation of Viscosity}

The viscosity measurement of the sodium alginate solution (1\% m:v) was carried out using a spindle S02 in Brookfield DV-E model Viscometer [40], with a speed of $100 \mathrm{rpm}$ at room temperature.

\subsection{Characterization of Sodium Alginate- ${ }^{1} H-N M R$ Spectroscopy Analysis}

The extracted sodium alginate was dissolved in $\mathrm{D}_{2} \mathrm{O}$ (deuterium dioxide) with a concentration of $6 \mathrm{~g} / \mathrm{L}$ at $80^{\circ} \mathrm{C}$, and the proton number was identified and confirmed by ${ }^{1} \mathrm{H}$ NMR experiments using a Bruker AVANCE 400 MHZ NMR spectrometer [41]. The NMR spectroscopy analysis was done based in studies of Fertah et al. [24], Belattmania et al. [42], Llanes et al. [43], and Jensen et al. [44].

The $\mathrm{M} / \mathrm{G}$ ratio, the molar fractions of the monads (FG and FM), and the dyad (FGG, FMM, FMG, and FGM) sequences were calculated from the area of ${ }^{1} \mathrm{H}$ NMR signals, employing the formula given by Belattmania et al. [42]:

$\mathrm{FG}=\mathrm{AI} /(\mathrm{AII}+\mathrm{AIII})$;

$\mathrm{FM}=1-\mathrm{FG}$;

FGG $=$ AIII/(AII + AIII);

$\mathrm{FGM}=\mathrm{FMG}=\mathrm{FG}-\mathrm{FGG}$;

$\mathrm{FMM}=\mathrm{FM}-\mathrm{FMG}$;

$\mathrm{M} / \mathrm{G}=(1-\mathrm{FG}) / \mathrm{FG}$;

$\eta=\mathrm{FMG} /(\mathrm{FM} \times \mathrm{FG})$;

$\mathrm{AI}$ is in the region of anomeric hydrogen of guluronic acid at 5.1-5.2 ppm, AII is at the anomeric hydrogens of mannuronic acid and the $\mathrm{H}-5$ of alternating blocks overlapping at 4.7-4.9 ppm, and AIII is the $\mathrm{H}-5$ of guluronic acid residues in the homopolymeric G blocks at $4.5-4.6 \mathrm{ppm}$.

\subsection{Characterization of Sodium Alginate_FTIR Analysis}

To identify the functional groups of the isolated sodium alginate, the Fourier Transform Infra-Red Spectroscopy (FTIR) method was used according to Kemp [45]. The dried sodium alginate was grounded into a fine powder $(<1 \mathrm{~mm})$ and mixed with dried $\mathrm{KBr}$ powder to make a homogeneous compressed thin tablet, and was then placed in a sample pan with the subsequent recording of the infrared spectrum using a Bruker Alpha FTIR spectrometer. All of the spectra were the average of two independent measurements from 4000 to $400 \mathrm{~cm}^{-1}$ with 128 scans, each at a resolution of $2 \mathrm{~cm}^{-1}$.

\subsection{Evaluation of Purity of Sodium Alginate by Qualitative Phytochemical Analysis}

To estimate the purity, an analysis for the existence of flavonoids, alkaloids, tannins, terpenoids, steroids, saponins, glycosides, phenols, and phlorotannins was done conforming to Trease and Evans [46] and Sofowora [47], which are rapid qualitative assays to verify the presence of possible impurities (other seaweed compounds in addition to the targeted compound).

\subsubsection{Test for Flavonoids}

To analyze the presence of flavonoids, a qualitative method was used. $0.5 \mathrm{~g}$ of sodium alginate was dissolved in diluted $\mathrm{NaOH}$ and then $\mathrm{HCl}$ was added. A yellow solution that turns colorless points to the existence of flavonoids. 


\subsubsection{Test for Alkaloids}

To analyze the presence of alkaloids, a qualitative method was used. First, $0.5 \mathrm{~g}$ of sodium alginate was dissolved in $10 \mathrm{~mL}$ of diluted $\mathrm{HCl}(0.1 \mathrm{~N})$ and was filtered. The filtrate was used to test the presence of alkaloids. Then, $1 \mathrm{~mL}$ of $1 \% \mathrm{HCl}$ was added to $3 \mathrm{~mL}$ of filtrate and was treated with few drops of Meyer's reagent. A creamy white precipitate indicated the existence of alkaloids.

\subsubsection{Test for Tannins}

To analyze the presence of tannins, a qualitative method was used. First, $0.5 \mathrm{~g}$ of sodium alginate was boiled with $10 \mathrm{~mL}$ of distilled water and was then filtered. A few drops of $0.1 \% \mathrm{FeCl}_{3}$ were added and observed for a blue-black or brownish green color, indicating the presence of tannins.

\subsubsection{Test for Phlorotannins}

To analyze the presence of phlorotannins, a qualitative method was used. First, $0.5 \mathrm{~g}$ of sodium alginate was dissolved in $5 \mathrm{~mL}$ of distilled water and filtered. The filtrate was boiled with a $2 \% \mathrm{HCl}$ solution. A red precipitate indicated the presence of phlorotannins.

\subsubsection{Test for Terpenoids and Steroids}

To analyze the presence of terpenoids and steroids, a qualitative method was used. First, $0.5 \mathrm{~g}$ of sodium alginate was added to $2 \mathrm{~mL}$ of chloroform. Then, $3 \mathrm{~mL}$ of conc. sulfuric acid was carefully added to form a layer. A reddish-brown color for the interface indicated the presence of terpenoids.

\subsubsection{Test for Saponins}

To analyze the presence of saponins, a qualitative method was used. First, $0.5 \mathrm{~g}$ of sodium alginate was dissolved in $5 \mathrm{~mL}$ of distilled water. The solution was shaken vigorously and observed for a stable persistent foam. The foaming was mixed with three drops of olive oil and shaken strongly and the formation of a milky mass was observed, which indicated the existence of saponins.

\subsubsection{Test for Glycosides}

The analysis of the presence of glycosides was done with a qualitative method using $0.5 \mathrm{~g}$ of sodium alginate dissolved in $5 \mathrm{~mL}$ of distilled water. Then, $10 \mathrm{~mL}$ of $50 \%$ sulfuric acid was added to $1 \mathrm{~mL}$ of this extract. The mixture was heated in boiling water for $5 \mathrm{~min}$. Then, $10 \mathrm{~mL}$ of Fehling's solution ( $5 \mathrm{~mL}$ of each solution A and B) was added and boiled. A brick red precipitate indicated the presence of glycosides.

\subsubsection{Test for Phenolic Compounds}

To analyze the presence of phenolic compounds, a qualitative method was used. First, $100 \mathrm{mg}$ of sodium alginate was boiled with $1 \mathrm{~mL}$ of distilled water and filtered. Then, $2 \mathrm{~mL}$ of filtrate was taken and $2 \mathrm{~mL}$ of $1 \% \mathrm{FeCl}_{3}$ solution was added. The establishment of bluish black color indicated the existence of phenol.

\subsection{Biochemical Analysis of Sodium Alginate}

\subsubsection{Carbohydrates Analysis}

The carbohydrate content of the sodium alginate was determined by the phenol sulphuric acid method described by Dubois et al. [48].

\subsubsection{Total Proteins Analysis}

The total proteins were tested following Lowry et al. [49]. The protein was calculated using bovine albumin serum as the standard and was expressed as \%DW. 


\subsubsection{Lipid's Analysis}

The total lipids were estimated gravimetrically using chloroform-methanol according to the AOAC methodologies [50].

\subsubsection{Ash Analysis}

The ash content was measured by a gravimetric method using AOAC [39] by burning $1 \mathrm{~g}$ of the product taken in a silica crucible and kept in a muffle furnace at $575{ }^{\circ} \mathrm{C}$ for $24 \mathrm{~h}$. After burning, the content was cooled, weighed, and expressed in terms of percentage.

\subsection{Statistical Analysis}

The data attained in this study were analyzed using one-way ANOVA at a 5\% significance level, and were expressed as average \pm SD. Further multiple comparisons by Fisher's grouping test were conducted using Minitab ${ }^{\circledR}$ (Version 19) software.

\section{Results}

\subsection{Sodium Alginate Yields}

The yield of sodium alginate of the five studied species is presented in Figure 3. The alginate content was significantly different between the species. The highest average was recorded in T. triquetra $(22.2 \pm 0.56 \% \mathrm{DW})$, while the lowest average was found in $H$. cuneiformis $(13.3 \pm 0.52 \% \mathrm{DW})$, demonstrating a fluctuation in the alginate yield between the species of $8.9 \%$.

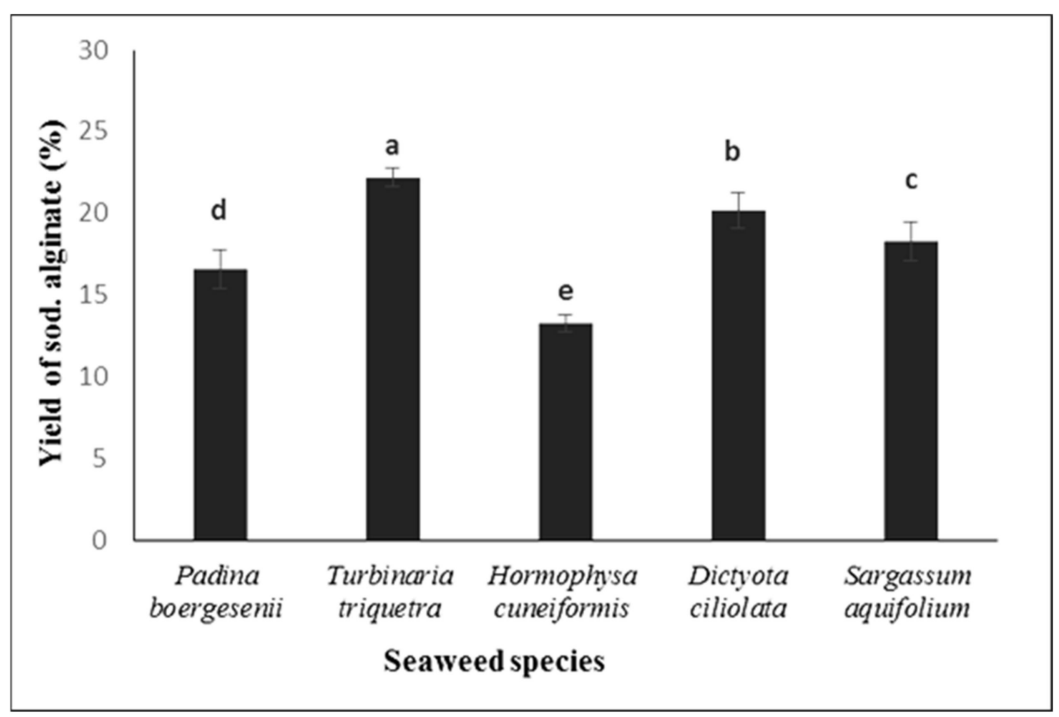

Figure 3. Extracted yield variations of sodium alginate (\% DW) between the examined brown algae species. Different letters indicate a significant difference at the level of $p \leq 0.05$.

\subsection{Physical Properties of Sodium Alginate}

The results of the measured physical-chemical properties, such as the color, $\mathrm{pH}$, moisture content, and viscosity of sodium alginate, are given in Table 2. The color of the extracted alginate for all of the species was pale-yellow. On the other hand, the alginate content of the selected seaweeds showed highly significant differences between species, as well as for the moisture content and viscosity, while there were no differences in the $\mathrm{pH}$ values. The highest level of moisture content was observed in P. boergesenii $(13.1 \pm 0.01 \%$ DW) when compared with the other species. The highest alginate viscosity was recorded in $H$. cuneiformis $(134.4 \pm 0.4 \mathrm{cP})$, while the lowest one was recorded in P. boergesenii $(57.6 \pm 0.2 \mathrm{cP})$. 
Table 2. Physical properties of sodium alginate extracted from the tested macroalgae.

\begin{tabular}{|c|c|c|c|c|c|}
\hline $\begin{array}{c}\text { Physical } \\
\text { Parameters }\end{array}$ & $\begin{array}{c}\text { Padina } \\
\text { boergesenii }\end{array}$ & $\begin{array}{c}\text { Turbinaria } \\
\text { triquetra }\end{array}$ & $\begin{array}{l}\text { Hormophysa } \\
\text { cuneiformis }\end{array}$ & Dictyota ciliolata & $\begin{array}{l}\text { Sargassum } \\
\text { aquifolium }\end{array}$ \\
\hline Colour & Pale-yellow & Pale-yellow & Pale-yellow & Pale-yellow & Pale-yellow \\
\hline $\mathrm{pH}$ & $9.72 \pm 0.2$ & $9.62 \pm 0.1$ & $9.63 \pm 0.20$ & $9.8 \pm 0.1$ & $9.76 \pm 0.1$ \\
\hline Moisture (\%) & $13.1 \pm 0.01^{\mathrm{a}}$ & $12 \pm 0.2^{c}$ & $6.4 \pm 0.1^{\mathrm{e}}$ & $9.7 \pm 0.02^{d}$ & $12.5 \pm 0.1^{b}$ \\
\hline Viscosity $(\mathrm{cP})^{*}$ & $57.6 \pm 0.2^{\mathrm{e}}$ & $124.4 \pm 0.1^{\mathrm{c}}$ & $134.4 \pm 0.4^{\mathrm{a}}$ & $108.1 \pm 0.2^{\mathrm{d}}$ & $128.4 \pm 0.3^{b}$ \\
\hline
\end{tabular}

${ }^{*}$ Values are expressed as average \pm standard deviation. ${ }^{\mathrm{a}, \mathrm{b}, \mathrm{c}, \mathrm{d}, \mathrm{e}}$ indicate a significant difference at the level of $p \leq 0.05$. ${ }^{*} \mathrm{cP}$ stands for centipoise.

\subsection{Sodium Alginate FTIR Spectroscopy Analysis}

The FTIR spectra of sodium alginate isolated from five brown macroalgae species are given in Figure 4 and Table 3. Broad bands at $3217 \mathrm{~cm}^{-1}, 3283 \mathrm{~cm}^{-1}, 3235 \mathrm{~cm}^{-1}, 3243 \mathrm{~cm}^{-1}$, and $3261 \mathrm{~cm}^{-1}$ were assigned to hydrogen bonded $(\mathrm{OH})$ for Padina boergesenii, Turbinaria triquetra, Hormophysa cuneiforms, Dictyota ciliolate, and Sargassum aquifolium, respectively, as shown in Table 3. The occurrence of two strong peaks around 1600 and $1400 \mathrm{~cm}^{-1}$ were assigned to asymmetric and symmetric stretching vibrations of carboxyl groups $(\mathrm{COOH})$ of alginate, respectively. The band around $1400 \mathrm{~cm}^{-1}$ represents the methylene $\mathrm{C}-\mathrm{H}$ stretch.

Table 3. FTIR frequency peak $\left(\mathrm{cm}^{-1}\right)$ and functional groups of the extracted sodium alginate.

\begin{tabular}{|c|c|c|c|c|c|}
\hline Functional Groups & P. boergesenii & T. triquetra & H. cuneiforms & D. ciliolata & S. aquifolium \\
\hline Hydrogen bonded O-H stretching vibration & 3217 & 3283 & 3235 & 3243 & 3261 \\
\hline $\mathrm{C}-\mathrm{H}$ stretching vibration & 2928 & 2916 & 2919 & 2920 & 2926 \\
\hline $\begin{array}{l}\text { Asymmetric stretching vibration of } \\
\text { carboxylate } \mathrm{O}-\mathrm{C}-\mathrm{O}\end{array}$ & 1602 & 1601 & 1596 & 1598 & 1597 \\
\hline $\begin{array}{l}\text { Symmetric stretching } \\
\text { vibration of carboxylate group }\end{array}$ & 1405 & 1402 & 1403 & 1402 & 1404 \\
\hline Guluronic units & 1082 & 1081 & 1081 & 1083 & 1084 \\
\hline Mannuronic units & 1023 & 1026 & 1025 & 1025 & 1025 \\
\hline $\mathrm{C}-\mathrm{O}$ stretching vibration of uronic acids & 947 & 947 & 945 & 947 & 947 \\
\hline $\mathrm{C}-\mathrm{H}$ of $\alpha$-L guluronic acid & 904 & 903 & 901 & 903 & 903 \\
\hline$\beta$-mannuronic acid residues & 870 & 874 & 873 & 872 & 872 \\
\hline
\end{tabular}

The anomeric region of carbohydrate was between 947 and $811 \mathrm{~cm}^{-1}$. The alginate FTIR spectra also showed the typical alginic acid peaks, which indicate the ratio of mannuronic and guluronic acid (ratio m:g, 870/900) and demonstrated an M/G ratio above 1.0, revealing a high content in the mannuronic acid units [23,42,51].

Moreover, the FTIR analysis demonstrated the absence of a peak in $1230-1280 \mathrm{~cm}^{-1}$ related with sulphated polysaccharides (such as fucoidan or laminarin), demonstrating a highly purified sodium alginate.

\section{4. ${ }^{1} \mathrm{H}-\mathrm{NMR}$ Spectroscopy Analysis of Sodium Alginate}

The results of the ${ }^{1} \mathrm{H}-\mathrm{NMR}$ structure of the extracted sodium alginate from the five seaweeds showed the existence of anomeric protons of guluronic acid and mannuronic acid, with three key signals attributed to the anomeric hydrogen of guluronic acid between 5.1-5.2 ppm, the anomeric hydrogens of mannuronic acid, the $\mathrm{H}-5$ of alternating blocks overlapping at $4.7-4.9 \mathrm{ppm}$, and the $\mathrm{H}-5$ of guluronic acid residues at $4.5-4.5 \mathrm{ppm}$. The ${ }^{1} \mathrm{H}$ NMR spectra of the extracted sodium alginates are shown in Figure 5, which are similar to the other selected seaweed alginate spectra. A high intense peak in the region of $4.7 \mathrm{ppm}$ is visible, demonstrating a high content in mannuronic acid. 


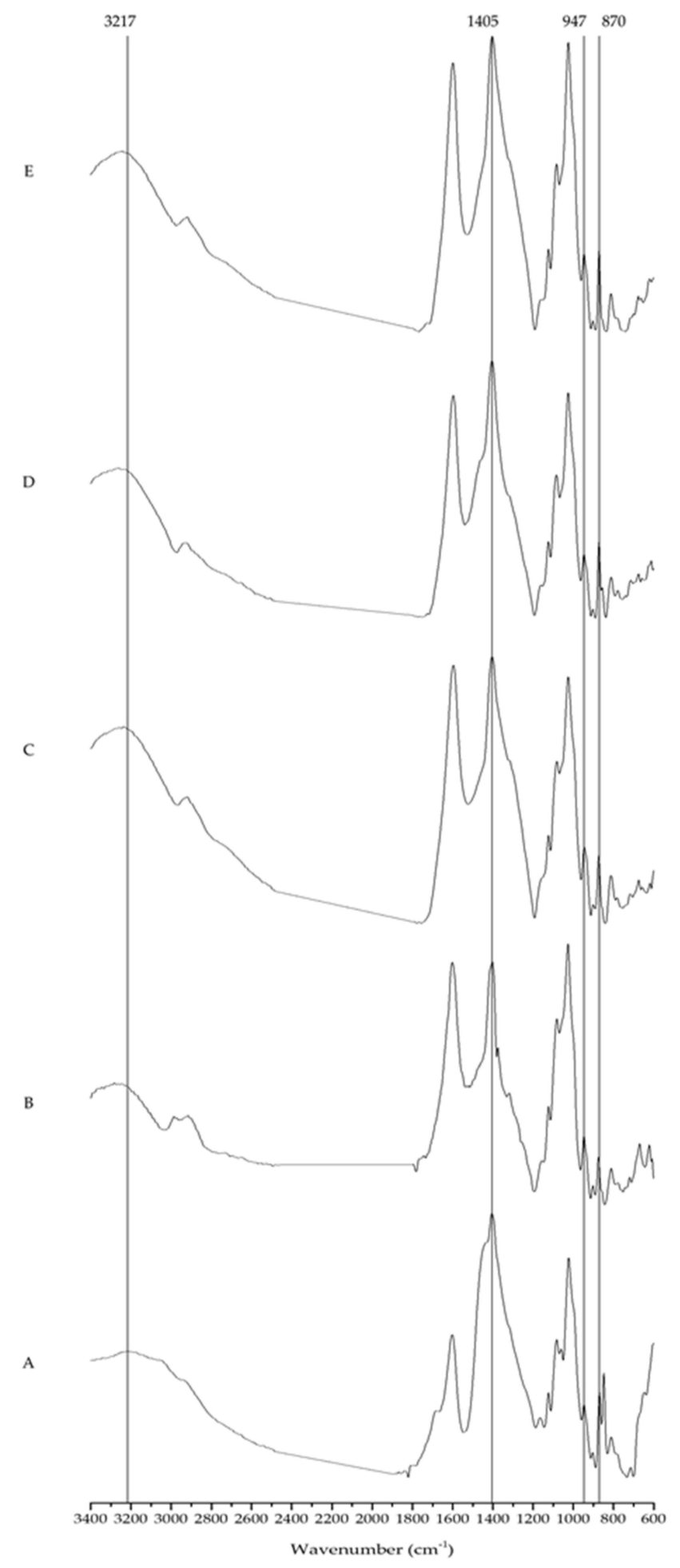

Figure 4. FTIR spectrum of sodium alginate isolated from five brown macroalgae: P. boergesenii (A), T. triquetra (B), H. cuneiformis (C), D. ciliolata (D), and S. aquifolium (E). 
A

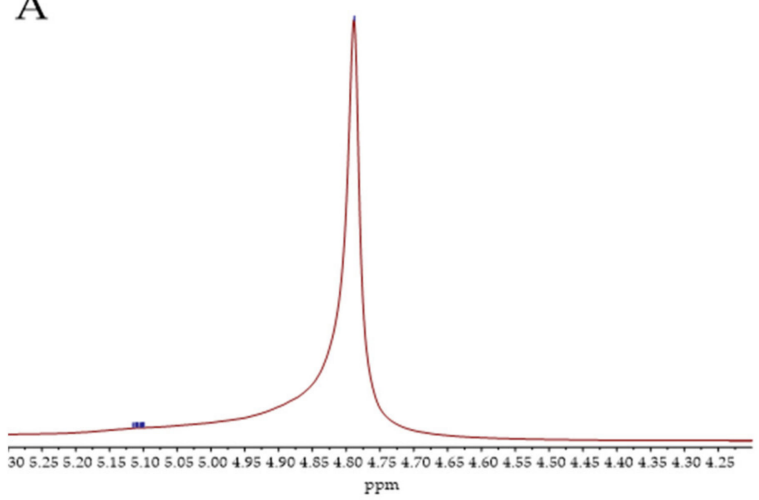

C

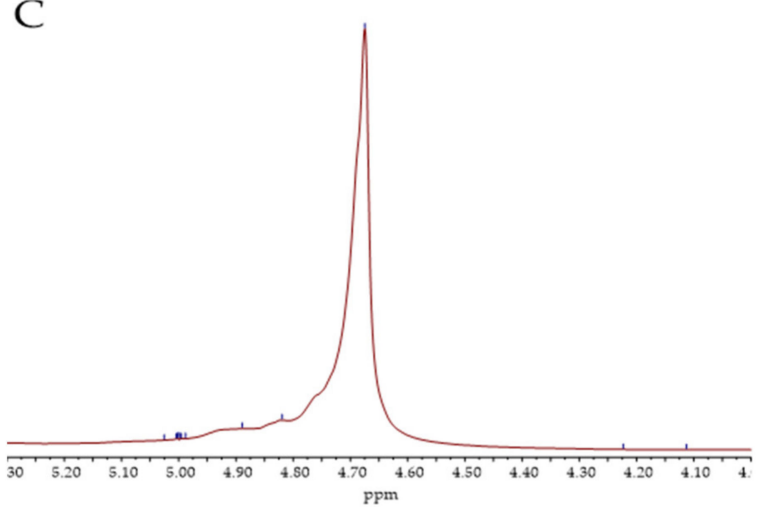

E
B

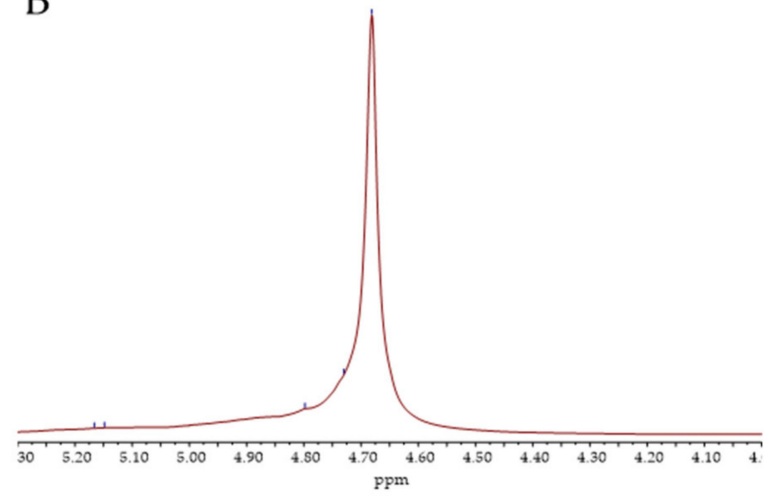

$\mathrm{D}$

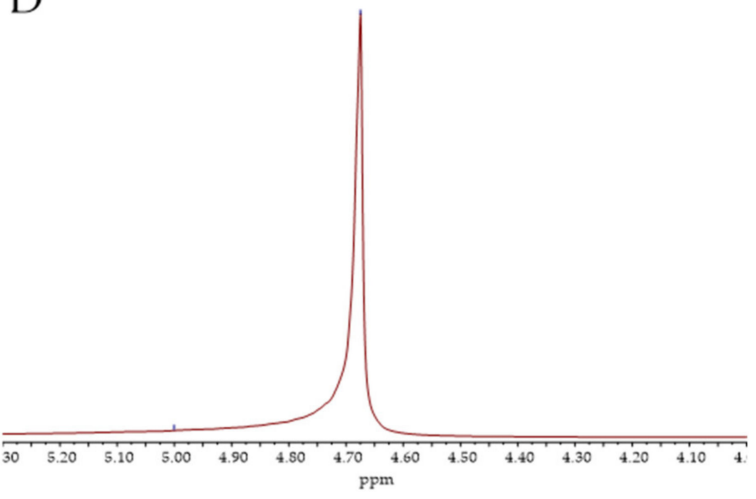

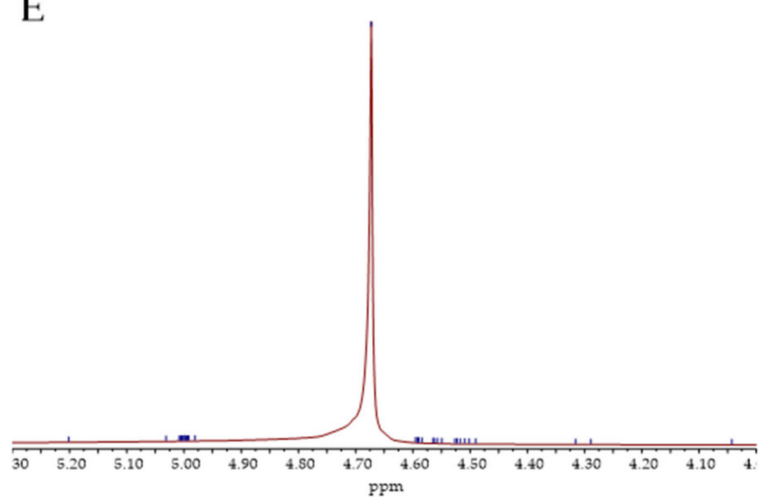

Figure 5. ${ }^{1} \mathrm{H}-\mathrm{NMR}$ spectra of the extracted sodium alginate from P. boergesenii (A), T. triquetra (B), H. cuneiformis (C), D. ciliolata (D), and S. aquifolium (E).

The $\mathrm{M} / \mathrm{G}$ ratios of the extracted sodium alginates were greater than 1 (Table 4 ), demonstrating a high dominance of mannuronic acid over guluronic acid, which was already described in the first analysis of Figure 5. Moreover, the alginate structure in these five seaweeds is mainly based in the monoblocs of mannuronic acid units with very few units of guluronic acid. Thus, the parameter $\eta$ demonstrates a high quantity of homopolymeric blocks, in this case, of MM. 
Table 4. Compositional data of the alginates extracted.

\begin{tabular}{ccccccccc}
\hline Species & $\mathbf{F}_{\mathbf{G}}$ & $\mathbf{F}_{\mathbf{G G}}$ & $\mathbf{F}_{\mathbf{M}}$ & $\mathbf{F}_{\mathbf{M G}}$ & $\mathbf{F}_{\mathbf{G M}}$ & $\mathbf{F}_{\mathbf{M M}}$ & $\mathbf{M} / \mathbf{G}$ & $\boldsymbol{\eta}$ \\
\hline P. boergesenii & 0.08 & 0.03 & 0.92 & 0.05 & 0.05 & 0.88 & 12.30 & 0.66 \\
T. triquetra & 0.15 & 0.14 & 0.85 & 0.01 & 0.01 & 0.85 & 5.80 & 0.06 \\
H. cuneiformis & 0.10 & 0.09 & 0.90 & 0.01 & 0.01 & 0.89 & 9.11 & 0.14 \\
D. ciliolata & 0.12 & 0.08 & 0.88 & 0.05 & 0.05 & 0.83 & 7.07 & 0.42 \\
S. aquifolium & 0.07 & 0.01 & 0.93 & 0.06 & 0.06 & 0.87 & 12.96 & 0.88 \\
\hline
\end{tabular}

$\mathrm{F}_{\mathrm{G}}$-guluronic acid ratio; $\mathrm{F}_{\mathrm{GG}}$-guluronic homopolymeric blocks; $\mathrm{F}_{\mathrm{M}}-$ mannuronic/guluronic acid ratio; $\mathrm{F}_{\mathrm{MG}}-$ heteropolymeric blocks mannuronic/guluronic acid; $\mathrm{F}_{\mathrm{GM}}$ - heteropolymeric blocks guluronic/mannuronic acid; $\mathrm{F}_{\mathrm{MM}}$ : mannuronic homopolymeric blocks; $\mathrm{M} / \mathrm{G}$-mannuronic/guluronic acid ratio; $\eta$ - relative abundance of homopolymeric blocks MM and GG $\eta=1$ for completely random cases and $1<\eta<2$ for alternate-like cases MG and GM.

\subsection{Determination of Purity of Sodium Alginate by Phytochemical Analysis}

The results showed that, in all of the extracted alginates, the phytochemical content, such as the terpenoids, flavonoids, alkaloids, tannins, glycosides, phlorotannins, phenols, and steroids, was absent. Only saponins were present in the extracted alginate of all of the studied species.

Thus, the qualitative analysis of the alginate demonstrated the absence of other seaweed metabolites, which can be prejudicial in the alginate application by diverse types of industries. Only saponins (a moiety of steroid and carbohydrates, which are sugar/carbohydrates derivatives) were present in all of the alginate extracted. These results established the high purity of the extracted alginate, with low impurity contents [52,53].

\subsection{Biochemical Composition of the Extracted Sodium Alginate}

The biochemical composition of the sodium alginate extracted from different brown seaweeds is given in Table 5. The seaweed carbohydrate yields were similar among the analyzed species (around 80\%) - the only species presenting a lower yield was P. boergesenii $(76.3 \pm 0.4 \% \mathrm{DW})$. The total lipid, protein, and ash contents of the extracted sodium alginate were highly significantly varied among species $(p=0.001)$. The sodium alginate of $D$. ciliolata showed the highest protein content $(1.47 \pm 0.2 \% \mathrm{DW})$ and the highest lipid content $(3.5 \pm 0.1 \% \mathrm{DW})$, whereas the lowest protein content was recorded in T. triquetra $(0.56 \pm 0.1 \% \mathrm{DW})$. The minimum lipid content was found in P. boergesenii $(0.3 \pm 0.09 \%$ DW). On the other hand, the sodium alginate of $P$. boergesenii showed the highest ash content $(20 \pm 1.2 \% \mathrm{DW})$. Thus, the alginate obtained had heterogeneity that was derivated from the seaweed species' in protein and lipid content, although the carbohydrate yield (alginate) was very high.

Table 5. Biochemical composition of the extracted sodium alginate.

\begin{tabular}{cccccc}
\hline Compound & P. boergesenii & T. triquetra & H. cuneiformis & D. ciliolata & S. aquifolium \\
\hline Carbohydrate & $76.3 \pm 0.4^{\mathrm{b}}$ & $81.2 \pm 0.1^{\mathrm{a}}$ & $80.5 \pm 0.3^{\mathrm{a}}$ & $82.5 \pm 0.2^{\mathrm{a}}$ & $83.1^{\mathrm{a}} \pm 0.1^{\mathrm{a}}$ \\
Protein & $0.86 \pm 0.2^{\mathrm{b}}$ & $0.57 \pm 0.1^{\mathrm{b}}$ & $0.68 \pm 0.5^{\mathrm{b}}$ & $1.47 \pm 0.2^{\mathrm{a}}$ & $0.952 \pm 0.1^{\mathrm{b}}$ \\
Lipid & $0.3 \pm 0.1^{\mathrm{c}}$ & $1.3 \pm 0.1^{\mathrm{b}}$ & $1.6 \pm 0.2^{\mathrm{b}}$ & $3.5^{\mathrm{b}} \pm 0.3^{\mathrm{a}}$ & $0.6 \pm 0.1^{\mathrm{c}}$ \\
Ash content & $20 \pm 1.2^{\mathrm{a}}$ & $15.5 \pm 2.2^{\mathrm{b}}$ & $16.3 \pm 1.6^{\mathrm{b}}$ & $12.3^{\mathrm{b}} \pm 0.8^{\mathrm{c}}$ & $15.2^{\mathrm{b}} \pm 0.9^{\mathrm{b}}$ \\
\hline
\end{tabular}

$\mathrm{a}, \mathrm{b}, \mathrm{c}$ indicate significant difference at the level of $p \leq 0.05$.

The alginate characterization demonstrates that these five unexploited and unstudied seaweeds have a similar alginate chemical characterization. However, T. triquetra demonstrated the highest average yield of sodium alginates $(22.2 \pm 0.56 \% \mathrm{DW})$, followed by $D$. ciliolata $(20.2 \pm 1.1 \% \mathrm{DW})$, with descending order of $T$. triquetra $>D$. ciliolata $>$ S. aquifolium $>P$. boergesenii $>H$. cuneiformis (Table 5 ). In the literature, these seaweeds have scarce information regarding their alginate yield and characterization. Only S. aquifolium and H. cuneiformis have data relative to the alginate yield. In S. aquifolium, the alginate yield was lower when compared with the same species collected at Ekas Bay (Lombok 
Island, Indonesia) (range: $24.26 \pm 0.08$ to $39.01 \pm 0.03 \%$ DW) [54]. The alginate yield in H. cuneiformis was lower in our study when compared with the study of Osman et al. [55] $(19.1 \%$ DW \pm 1.62$)$ in the Red Sea Coast in the Sudan region. However, the alginate yields obtained in this study were in accordance with the range of the alginate yields of the alginophytes species analyzed by Rioux et al. [56], such as Macrocystis pyrifera (1-21\% DW), Ascophyllum nodosum (15-20\% DW), and Saccharina japonica (20-26\% DW) (normally used as a raw source by the alginate industry). However, a lower percentage than the alginate extracted from Durvillaea antarctica (from 37 to $52 \%$ DW) by Panikkar and Brasch was observed [57]. As stated by Dobrinčić et al. [58], the yield of alginate extraction depends on the seaweed's age and the species used and the environmental conditions, such as light intensity, water temperature, currents, and nutritional status, as well as the extraction techniques.

Moreover, the alginate yield demonstrates the seaweed's potential as a dietary fiber raw source to humans for direct consumption, as they are important for human welfare [59]. The results demonstrate that the selected seaweed's potential as a dietary fiber source for human ingestion is within the limits (Table 6) [60]. The recommended dietary fiber intake (RDFI) is $25 \mathrm{~g} /$ day for a normal adult person; above this limit, there is a possibility of the appearance of an dietary fiber-related adverse effects in human health [1,59]. Nevertheless, because of the large miscellany of seaweeds compounds, principally their mineral content, the recommended daily intake for a nonspecific seaweed is typically only $5 \mathrm{~g}$ DW/day to a human $[61,62]$. In this case, the seaweed intake represents a low consumption, however important, of dietary fiber (RDFI between 2.68 and $4.44 \%$ /day) to the human health, because of the positive effects of the alginate cited above, even at a low percentage (for example, anti-obesity and anti-diabetes activities of alginate is observed at a concentration lower than $0.1 \%$ ) [63].

Table 6. Thresholds of daily consumption of seaweeds based on their polysaccharide content.

\begin{tabular}{ccccc}
\hline Species & $\begin{array}{c}\text { \% of Dietary } \\
\text { Fiber/Seaweed DW }\end{array}$ & $\begin{array}{c}\text { g of Seaweed DW for } \\
\text { 25 g of Dietary Fiber }\end{array}$ & $\begin{array}{c}\text { g of Dietary Fiber for } \mathbf{5} \\
\text { g of Seaweed DW }\end{array}$ & $\begin{array}{c}\text { \% of the RDFI/5g of } \\
\text { Seaweed DW }\end{array}$ \\
\hline D. ciliolata & $20.2 \pm 1.1$ & 123.76 & 1.01 & 4 \\
H. cuneiformis & $13.3 \pm 0.52$ & 187.97 & 0.67 & 2.68 \\
P. boergesenii & $16.6 \pm 1.2$ & 150.60 & 0.83 & 3.32 \\
S. aquifolium & $18.3 \pm 1.2$ & 136.61 & 0.92 & 3.68 \\
T. triquetra & $22.2 \pm 0.56$ & 112.61 & 1.11 & 4.44 \\
\hline
\end{tabular}

Consequently, these seaweeds can be further explored as a natural and unprocessed food source. In this case, seaweed is directly used as a food source as an alternative to traditional dietary fiber sources, such as fruits, vegetables, oat bran, barley, seed husks, flaxseed, psyllium, dried beans, and lentils [64].

To be exploited by the food industry, the extracted alginate needs to be evaluated so as to overview its potential to be accepted as a safe ingredient at an industrial level. For this, there is a need to characterize the alginate extract with various physicochemical methods so as to certify the alginate's quality [1]. Consequently, this study aimed to give an insight into the sodium alginate quality of the selected seaweeds.

The physical analysis showed that the obtained sodium alginate had a pale-yellow color and its moisture content varied between 6.4 to $13.1 \%$. These results demonstrate that these seaweeds' alginate is good according to the FAO report written by Coppen [65], where it is stated that the color of sodium alginate is white to yellowish-brown and the moisture content is $15 \%$.

The $\mathrm{pH}$ value of the obtained sodium alginate showed an alkaline nature and ranged between 9.6 and 9.8. Bahar et al. [66] reported that sodium alginate is stable at a $\mathrm{pH}$ range from 5 to 10; furthermore, the Food Chemical Codex (FCC) [67] has established that the food quality of sodium alginate in the food industry needs to be at $\mathrm{pH} 3.5-10$. When comparing the results of the extracted sodium alginate with these standards, it can 
be concluded that they are in accordance with the quality standards established by the food industry.

The rheological features are a key factor in the use and application of alginates in the food industry [7]. In the present study, the viscosity of sodium alginate was significantly different between species, ranging from 57.6 to $134.4 \mathrm{cP}$. However, the results obtained are in accordance with the FCC standard. The FCC authorizes sodium alginate viscosities between 10 to $5000 \mathrm{cP}$. Nevertheless, the viscosity of the alginate is affected by several factors, such as the proportion of $\mathrm{M}$ and $\mathrm{G}$ units in the extracted alginate, the temperature, and the acidic media [68].

To determine and identify the presence of functional groups in alginate, FTIR spectroscopy analysis was used $[23,69]$. In this study, the FTIR analysis revealed that the band at $947 \mathrm{~cm}^{-1}$ (elongation vibration $\mathrm{C}-\mathrm{O}$ of uronic acid residues) and the small band at $903 \mathrm{~cm}^{-1}$ are attributed to $\mathrm{C}-\mathrm{H}$ of $\alpha$-L guluronic acid. Mannuronic units have a band at approximately $1025 \mathrm{~cm}^{-1}$, while guluronic units have a band at $1082 \mathrm{~cm}^{-1}$. The $872 \mathrm{~cm}^{-1}$ band is typical of $\beta$-mannuronic acid residues. In our spectrum, it was observed that the presence of a band around $1025 \mathrm{~cm}^{-1}$ (M blocks) is slightly more intense than the band around $1082 \mathrm{~cm}^{-1}$ (G blocks), suggesting that our alginate is slightly richer in mannuronic residues than in guluronic residues $[23,42,70]$. However, this method lacks quantification precision. All of the spectra of isolated alginates are very comparable to those of commercial standard sodium alginate (Sigma-Aldrich, Gillingham, UK), as reported by Belattmania et al. [42], showing similar locations of the characteristic bands.

Furthermore, when using FTIR, it the peaks of other compounds were not detected, such as Phlorotannins or carotenoids, which can be bonded to alginate in the seaweed cell walls [71].

For the determination of the composition, structure, $\mathrm{M} / \mathrm{G}$ ratio, and block distribution of alginates, ${ }^{1} \mathrm{H}-\mathrm{NMR}$ was used [69]. The sodium alginate extracted from all of the studied brown algae revealed characteristic spectra similar to the commercial sodium alginate, as reported by Belattmania et al. [42]. This study [42] also demonstrates that alginates with a high $M / G$ ratio have more elastic tension, which is more desirable for the food industry (as a thickener, gel, emulsifier, flavor enhancer, and stabilizer), and also in cosmetic or pharmaceutical areas [42,72]. Although with similar conformation, the alginate viscosity difference can be derivated in the alternance of GG, MM, or MG units within the species analyzed, which are important to alginate viscosity and moisture retention [42]. Additionally, other impurities that alginate has, such as proteins and lipids, also contribute to variations in viscosity.

Another important parameter to analyze before applying sodium alginate in the food and biomedical fields is the alginate purity yield. The phytochemical characteristics results indicate that the sodium alginate extracted from different brown seaweeds do not have terpenoids, tannins, glycosides, phlorotannins, flavonoids, phenols, steroids, and alkaloids. Similarly, Sivagnanavelmurugan et al. [12] and Kavitha et al. [50] have determined the purity of alginic acid, which indicates the absence of tannins, flavonoids, phenols, steroids, and alkaloids; however, only saponins (due to be moiety with carbohydrates) were found, which supports the high purity of the extracted alginates.

The biochemical assays demonstrated that the highest protein content in the alginate was found in D. ciliolata and the lowest was in T. triquetra. The quantitative analysis ranged from 0.57 to $1.4 \%$. The lipid content of the alginate ranged from 0.3 to $3.5 \%$. The maximum content was found in D. ciliolata, whereas $P$. boergesenii recorded the minimum content. Similarly, Viswanathan and Nallamuthu [73] reported a maximum lipid content, which was $6.12 \%$, in D. ciliolate, and the protein content was $4 \%$. In general, the protein content fluctuates among different genera and in different species of the same genus, and this change may be spatial or temporal in nature. However, it is largely associated with the seawater quality, as stated by El-Manawy et al. [74]. The value of the ash content of the sodium alginate in this study varied between 12.3 and $20 \%$. These results do not differ much from the ash content established by the Food Chemical Codex [67], which varied 
from 13 to $27 \%$. Similarly, Chapman and Chapman [75] reported that the ash content is $23 \%$. When compared to global standards, the ash contents of the extracted sodium alginates were in accordance with these standards.

Considering the results of the alginate yield and all of the analyses done, it is supported by the spectroscopy methods (FTIR and NMR) that these seaweeds' alginate has a high mannuronic acid concentration with low content of other sulphated polysaccharide, although the viscosity of the alginates varies greatly due to the mannuronic and guluronic acid ratio. Using the phytochemical analysis supported the clean extraction of the alginate without other seaweed compounds. In contrast, the biochemical analysis gives an overall analysis of the alginate, where proteins and lipids were detected at a low percentage. Thus, these results unveil the potential of these five seaweeds for further industrial exploitation of alginate for food industries. Although T. triquetra had a higher alginate yield and also one of the highest percentages of carbohydrates, S. aquifolium was the third in alginate yield, and it presented a higher percentage of carbohydrates (less impurities). D. ciliolata was the second in alginate yield and in the carbohydrate yield, which demonstrates a good raw source for alginate extraction, although this species has a high protein and lipid yield, which is a problem to be surpassed. P. boergesenii and H. cuneiformis had the lowest alginate yield and carbohydrate yield, however, these species can be also a new source if there is a high biomass concentration of these species for alginate extraction.

\section{Conclusions}

The alginate content from the different species was higher than $16 \%$ DW in the studied species, except in H. cuneiformis, which recorded the lowest average (13.3\%), demonstrating an interesting dietary fiber content as a nutraceutical food source.

The spectroscopic techniques (FTIR and NMR analysis) and physicochemical analyses showed similarity between the extracted alginates of the selected species and with the reported commercial worldwide alginates. It can be concluded that the alginates extracted from Turbinaria triquetra, Sargassum aquifolium, Dictyota dichotoma, Padina boergesenii, and Hormophysa cuneiforms can be considered as candidates for alginophyte industrial exploitation to the exploitation of mannuronic acid-enriched alginate, which is indicated to develop elastic gels and be applied in food products.

Moreover, the alginate extracted from the five selected seaweeds also demonstrated a food grade quality when compared with the alginate international regulation, and this acknowledgment can be exploited by the food industry to be applied in various processed products because of the viscosity difference among the seaweeds analyzed. However, before exploitation, there is a need to assess the molecular weight, in order to determine the alginate's high molecular weight. In addition, the storage time and possible changes in the alginate yield/characterization are needed for these seaweeds' safe exploitation.

Author Contributions: Conceptualization, methodology, validation, and investigation, S.H.R., M.S.M.A.E.H., M.A.D.; writing—original draft preparation, S.H.R., M.S.M.A.E.H., M.A.D., J.C. and L.P.; writing—review and editing, S.H.R., J.C. and L.P.; supervision, S.H.R. and L.P. All of the authors have read and agreed to the published version of the manuscript.

Funding: This research received no external funding.

Institutional Review Board Statement: Not applicable.

Informed Consent Statement: Not applicable.

Data Availability Statement: Data available from authors.

Acknowledgments: This work was financed by national funds through FCT (Foundation for Science and Technology), I.P., within the scope of the projects UIDB/04292/2020 (MARE-Marine and Environmental Sciences Centre). João Cotas wishes to thank the European Regional Development Fund through the Interreg Atlantic Area Program, under project NASPA (EAPA_451/2016).

Conflicts of Interest: The authors declare no conflict of interest. 


\section{References}

1. Leandro, A.; Pacheco, D.; Cotas, J.; Marques, J.C.; Pereira, L.; Gonçalves, A.M.M. Seaweed's bioactive candidate compounds to food industry and global food security. Life 2020, 10, 140. [CrossRef] [PubMed]

2. Pereira, L.; Cotas, J. Introductory chapter: Alginates-A general overview. In Alginates—Recent Uses of This Natural Polymer; IntechOpen: London, UK, 2020.

3. Brown, E.M.; Allsopp, P.J.; Magee, P.J.; Gill, C.I.; Nitecki, S.; Strain, C.R.; McSorley, E.M. Seaweed and human health. Nutr. Rev. 2014, 72, 205-216. [CrossRef]

4. Chen, L.; Xu, W.; Chen, D.; Chen, G.; Liu, J.; Zeng, X.; Shao, R.; Zhu, H. Digestibility of sulfated polysaccharide from the brown seaweed Ascophyllum nodosum and its effect on the human gut microbiota in vitro. Int. J. Biol. Macromol. 2018, 112, 1055-1061. [CrossRef]

5. Cherry, P.; Yadav, S.; O'Callaghan, C.; Popper, Z.A.; Ross, R.P.; McSorley, E.M.; Allsopp, P.J.; Stanton, C. In-vitro fermentation of whole seaweed and a polysaccharide-rich extract derived from the edible red seaweed Palmaria palmata. Proc. Nutr. Soc. 2016, 75, E57. [CrossRef]

6. Peteiro, C. Alginate production from marine macroalgae, with emphasis on kelp farming. In Alginates and Their Biomedical Applications; Rehm, B., Moradali, M., Eds.; Springer: Singapore, 2018; pp. 27-66.

7. Fenoradosoa, T.A.; Ali, G.; Delattre, C.; Laroche, C.; Petit, E.; Wadouachi, A.; Michaud, P. Extraction and characterization of an alginate from the brown seaweed Sargassum turbinarioides Grunow. J. Appl. Phycol. 2010, 22, 131-137. [CrossRef]

8. Rhein-Knudsen, N.; Ale, M.T.; Ajalloueian, F.; Meyer, A.S. Characterization of alginates from Ghanaian brown seaweeds: Sargassum spp. and Padina spp. Food Hydrocoll. 2017, 71, 236-244. [CrossRef]

9. Mazumder, A.; Holdt, S.L.; De Francisci, D.; Alvarado-Morales, M.; Mishra, H.N.; Angelidaki, I. Extraction of alginate from Sargassum muticum: process optimization and study of its functional activities. J. Appl. Phycol. 2016, 28, 3625-3634. [CrossRef]

10. Batista, P.S.P.; de Morais, A.M.M.B.; Pintado, M.M.E.; de Morais, R.M.S.C. Alginate: Pharmaceutical and Medical Applications; Springer: Berlin, Germany, 2019; pp. 649-691.

11. Rinaudo, M. Biomaterials based on a natural polysaccharide: Alginate. TIP 2014, 17, 92-96. [CrossRef]

12. Sivagnanavelmurugan, M.; Radhakrishnan, S.; Palavesam, A.; Arul, V.; Immanuel, G. Characterization of alginic acid extracted from Sargassum wightii and determination of its anti-viral activity of shrimp Penaeus monodon post larvae against white spot syndrome virus. Int. J. Curr. Res. Life Sci. 2018, 7, 1863-1872.

13. Zubia, M.; Stiger-Pouvreau, V.; Mattio, L.; Payri, C.E.; Stewart, H.L. A comprehensive review of the brown macroalgal genus Turbinaria J.V. Lamouroux (Fucales, Sargassaceae). J. Appl. Phycol. 2020, 32, 2743-2760. [CrossRef]

14. Vauchel, P.; Kaas, R.; Arhaliass, A.; Baron, R.; Legrand, J. A new process for extracting alginates from Laminaria digitata: Reactive Extrusion. Food Bioprocess Technol. 2008, 1, 297-300. [CrossRef]

15. Lee, K.Y.; Mooney, D.J. Alginate: Properties and biomedical applications. Prog. Polym. Sci. 2012, 37, 106-126. [CrossRef]

16. Younes, M.; Aggett, P.; Aguilar, F.; Crebelli, R.; Filipič, M.; Frutos, M.J.; Galtier, P.; Gott, D.; Gundert-Remy, U.; Kuhnle, G.G.; et al. Re-evaluation of alginic acid and its sodium, potassium, ammonium and calcium salts (E 400-E 404) as food additives. EFSA J. 2017, 15, e05049.

17. Food and Drug Administration. Section 184.1724 of the Federal Food and Drug Administration Act (21CFR184.1724). Code of Federal Regulations Title 21, Electronic Code of Federal Regulations (eCFR); Food and Drug Administration: Silver Spring, MA, USA, 2020; Volume 3, p. 164.

18. EFSA Panel on Dietetic Products, Nutrition and Allergies (NDA). Scientific Opinion on the substantiation of health claims related to dietary fibre (ID 744, 745, 746, 748, 749, 753, 803, 810, 855, 1415, 1416, 4308, 4330) pursuant to Article 13(1) of Regulation (EC) No 1924/2006. EFSA J. 2010, 8, 1735. [CrossRef]

19. Cherry, P.; O’Hara, C.; Magee, P.J.; Mcsorley, E.M.; Allsopp, P.J. Risks and benefits of consuming edible seaweeds. Nutr. Rev. 2019, 77, 307-329. [CrossRef] [PubMed]

20. Gheorghita Puscaselu, R.; Lobiuc, A.; Dimian, M.; Covasa, M. Alginate: From food industry to biomedical applications and management of metabolic disorders. Polymers 2020, 12, 2417. [CrossRef]

21. Sudha, P.N. (Ed.) Industrial Applications of Marine Biopolymers; CRC Press: Boca Raton, FL, USA, 2017 ; ISBN 9781315313535.

22. Hernández-Carmona, G.; Freile-Pelegrín, Y.; Hernández-Garibay, E. Conventional and alternative technologies for the extraction of algal polysaccharides. In Functional Ingredients from Algae for Foods and Nutraceuticals; Elsevier: Amsterdam, The Netherlands, 2013; pp. 475-516.

23. Pereira, L.; Gheda, S.F.; Ribeiro-Claro, P.J.A. Analysis by Vibrational Spectroscopy of Seaweed Polysaccharides with Potential Use in Food, Pharmaceutical, and Cosmetic Industries. Int. J. Carbohydr. Chem. 2013, 2013, 1-7. [CrossRef]

24. Fertah, M.; Belfkira, A.; Dahmane, E.M.; Taourirte, M.; Brouillette, F. Extraction and characterization of sodium alginate from Moroccan Laminaria digitata brown seaweed. Arab. J. Chem. 2017, 10, S3707-S3714. [CrossRef]

25. Arunkumar, K. Extraction, Isolation, and Characterization of Alginate. In Industrial Applications of Marine Biopolymers; CRC Press: Boca Raton, FL, USA, 2017; pp. 19-35.

26. Global Alginate Market Size I Industry Report, 2021-2028. Available online: https:/ /www.grandviewresearch.com/industryanalysis/alginate-market (accessed on 31 March 2021).

27. Omar, H.H.; Abdullatif, B.M.; El-Kazan, M.M.; El-Gendy, A.M. Red sea water and biochemical composition of seaweeds at southern coast of Jeddah, Saudi Arabia. Life Sci. J. 2013, 10, 1073-1080. 
28. Moubayed, N.M.S.; Al Houri, H.J.; Al Khulaifi, M.M.; Al Farraj, D.A. Antimicrobial, antioxidant properties and chemical composition of seaweeds collected from Saudi Arabia (Red Sea and Arabian Gulf). Saudi J. Biol. Sci. 2017, 24, 162-169. [CrossRef]

29. El-Manawy, I.M.; Nassar, M.Z.; Fahmy, N.M.; Rashedy, S.H. Evaluation of proximate composition, antioxidant and antimicrobial activities of some seaweeds from the Red Sea coast, Egypt. Egypt. J. Aquat. Biol. Fish. 2019, 23, 317-329. [CrossRef]

30. Kamal, H. Seaweed as Health Status Indicator for Ghardaqah Coral Reef. Master's Thesis, Environmental Science Department, Faculty of Science, Suez Canal University, El Sheikh Zayed, Egypt, 2014.

31. El-Manawy, I. The spatial variability of macroalgal communities and their functional groupings on the fringing reefs of Ghardaqah, Egypt. Egypt. J. Phycol. 2008, 9, 55-69. [CrossRef]

32. Rashedy, S.H. Spatial and Temporal Variations in Nutritional Composition, Antioxidant and Antimicrobial Activities of Some Seaweeds from Red Sea, Egypt. Ph.D. Thesis, Suez Canal University, El Sheikh Zayed, Egipt, 2019.

33. Papenfuss, G.F. A history, catalogue, and bibliography of Red Sea benthic algae. Isr. J. Bot. 1968, 17, 1-118.

34. Aleem, A.A. A preliminary list of marine algae from sierra Leone. Bot. Mar. 1978, 17, 397-399.

35. Coppejans, E.; Beeckman, T. Caulerpa (Chlorophyta, Caulerpales) from the Kenyan coast. Nov. Hedwigia 1990, 50, 111-125. [CrossRef]

36. Sahoo, D. Seaweeds of Indian Coast; APH Publishing Corporation: New Delhi, India, 2001.

37. Guiry, M.D.; Guiry, G.M. Algaebase: Listing the World's Algae. Available online: https://www.algaebase.org/ (accessed on 27 June 2020).

38. Torres, M.R.; Sousa, A.P.A.; Silva Filho, E.A.T.; Melo, D.F.; Feitosa, J.P.A.; de Paula, R.C.M.; Lima, M.G.S. Extraction and physicochemical characterization of Sargassum vulgare alginate from Brazil. Carbohydr. Res. 2007, 342, 2067-2074. [CrossRef]

39. AOAC International. Official Methods of Analysis, 16th ed.; AOAC International: Washington, DC, USA, 1995.

40. Cottrell, L.W.; Kovacs, P. Alginates. In Handbook of Water-Soluble Gums and Resins; Davidson, R., Ed.; Mc-Graw-Hill: New York, NY, USA, 1980; p. 671.

41. Jayaprakash, N.; Kalaiselvi, N. On the electrochemical behavior of LiMXFe1-XPO4 [M=Cu, Sn; X=0.02] anodes-An approach to enhance the anode performance of LiFePO4 material. Electrochem. Commun. 2007, 9, 620-628. [CrossRef]

42. Belattmania, Z.; Kaidi, S.; El Atouani, S.; Katif, C.; Bentiss, F.; Jama, C.; Reani, A.; Sabour, B.; Vasconcelos, V. Isolation and FTIR-ATR and $1 \mathrm{H}$ NMR characterization of alginates from the main alginophyte species of the atlantic coast of Morocco. Molecules 2020, 25, 4335. [CrossRef]

43. Llanes, F.; Sauriol, F.; Morin, F.G.; Perlin, A.S. An examination of sodium alginate from Sargassum by NMR spectroscopy. Can. J. Chem. 1997, 75, 585-590. [CrossRef]

44. Jensen, H.M.; Larsen, F.H.; Engelsen, S.B. Characterization of Alginates by Nuclear Magnetic Resonance (NMR) and Vibrational Spectroscopy (IR, NIR, Raman) in Combination with Chemometrics. In Products From Marine Algae. Methods in Molecular Biology; Stengel, D., Connan, S., Eds.; Humana Press Inc.: New York, NY, USA, 2015; Volume 1308, pp. 347-363.

45. Kemp, W. Organic Spectroscopy; Macmillan Education: London, UK, 1991; ISBN 978-1-4039-0684-7.

46. Trease, G.E.; Evans, W.C. Pharmacognosy, 13th ed.; Baillière Tindall: London, UK, 1989.

47. Sofowora, A. Medicinal Plants and Traditional Medicine in Africa, 2nd ed.; Spectrum Books Limited, Sunshine House: Ibadan, Nigeria, 1993.

48. DuBois, M.; Gilles, K.A.; Hamilton, J.K.; Rebers, P.A.; Smith, F. Colorimetric method for determination of sugars and related substances. Anal. Chem. 1956, 28, 350-356. [CrossRef]

49. Lowry, O.H.; Rosebrough, N.J.; Farr, A.L.; Randall, R.J. Protein measurement with the Folin phenol reagent. J. Biol. Chem. 1951, 193, 265-275. [CrossRef]

50. AOAC International. Official Methods of Analysis, 17th ed; AOAC International: Washington, DC, USA, 2000.

51. Flórez-Fernández, N.; Domínguez, H.; Torres, M.D. A green approach for alginate extraction from Sargassum muticum brown seaweed using ultrasound-assisted technique. Int. J. Biol. Macromol. 2019, 124, 451-459. [CrossRef] [PubMed]

52. Kavitha, N.; Karunya, T.P.; Kanchana, S.; Mohan, K.; Sivaramakrishnan, R.; Uthra, S.; Kapilan, K.; Yuvaraj, D.; Arumugam, M. Formulation of alginate based hydrogel from brown seaweed, Turbinaria conoides for biomedical applications. Heliyon 2019, 5, e02916. [CrossRef]

53. Zu, L.; Zhao, Y.; Gu, G. Recent development in the synthesis of natural saponins and their derivatives. J. Carbohydr. Chem. 2014, 33, 269-297. [CrossRef]

54. Setyawidati, N.A.R.; Puspita, M.; Kaimuddin, A.H.; Widowati, I.; Deslandes, E.; Bourgougnon, N.; Stiger-Pouvreau, V. Seasonal biomass and alginate stock assessment of three abundant genera of brown macroalgae using multispectral high resolution satellite remote sensing: A case study at Ekas Bay (Lombok, Indonesia). Mar. Pollut. Bull. 2018, 131, 40-48. [CrossRef] [PubMed]

55. Osman, N.; Suliman, T.; Osman, K. Characterization of native alginates of common alginophytes from the red sea coast of Sudan. Int. J. Second. Metab. 2020, 7, 266-274. [CrossRef]

56. Rioux, L.-E.; Turgeon, S.L.; Beaulieu, M. Characterization of polysaccharides extracted from brown seaweeds. Carbohydr. Polym. 2007, 69, 530-537. [CrossRef]

57. Panikkar, R.; Brasch, D.J. Composition and block structure of alginates from New Zealand brown seaweeds. Carbohydr. Res. 1996, 293, 119-132. [CrossRef]

58. Dobrinčić, A.; Balbino, S.; Zorić, Z.; Pedisić, S.; Bursać Kovačević, D.; Elez Garofulić, I.; Dragović-Uzelac, V. Advanced technologies for the extraction of marine brown algal polysaccharides. Mar. Drugs 2020, 18, 168. [CrossRef] 
59. EFSA. Panel on Dietetic Products, Nutrition, and Allergies (NDA). Scientific opinion on dietary reference values for carbohydrates and dietary fibre. EFSA J. 2010, 8, 1462.

60. Cotas, J.; Pacheco, D.; Araujo, G.S.; Valado, A.; Critchley, A.T.; Pereira, L. On the health benefits vs. risks of seaweeds and their constituents: The curious case of the polymer paradigm. Mar. Drugs 2021, 19, 164. [CrossRef]

61. Teas, J. Dietary Seaweed and Breast Cancer: A Randomized Trial; Defense Technical Information Center: Columbia, SC, USA, 2005.

62. Teas, J.; Braverman, L.E.; Kurzer, M.S.; Pino, S.; Hurley, T.G.; Hebert, J.R. Seaweed and soy: Companion Foods in Asian cuisine and their effects on thyroid function in american women. J. Med. Food 2007, 10, 90-100. [CrossRef]

63. Brownlee, I.A.; Allen, A.; Pearson, J.P.; Dettmar, P.W.; Havler, M.E.; Atherton, M.R.; Onsøyen, E. Alginate as a source of dietary fiber. Crit. Rev. Food Sci. Nutr. 2005, 45, 497-510. [CrossRef] [PubMed]

64. Fibre in Food-Better Health Channel. Available online: https://www.betterhealth.vic.gov.au/health/HealthyLiving/fibre-infood (accessed on 31 March 2021).

65. Coppen, J.J.W. Gums, Resins and Latexes of Plant Origin; FAO: Rome, Italy, 1995; ISBN 9251037574.

66. Bahar, R.; Arief, A. Sukriadi Inhibition of Na-alginate extract from brown algae Sargassum sp. on the ripening process of mangoes and oranges. J. Indones. Chim. Acta. 2012, 2, 22-31.

67. Food Chemicals Codex; National Academies Press: Washington, DC, USA, 1981; ISBN 978-0-309-03090-8.

68. Husni, A.; Subaryono, S.; Pranoto, Y.; Taswir, T.; Ustadi, U. Pengembangan metode ekstraksi alginat dari rumput laut Sargassum sp. sebagai bahan pengental (Development of Alginate Extraction Method from Sargassum sp. as Thickening). Agritech 2012, 32, 1. [CrossRef]

69. Janarthanan, M.; Senthil Kumar, M. Extraction of alginate from brown seaweeds and evolution of bioactive alginate film coated textile fabrics for wound healing application. J. Ind. Text. 2019, 49, 328-351. [CrossRef]

70. El Atouani, S.; Bentiss, F.; Reani, A.; Zrid, R.; Belattmania, Z.; Pereira, L.; Mortadi, A.; Cherkaoui, O.; Sabour, B. The invasive brown seaweed Sargassum muticum as new resource for alginate in Morocco: Spectroscopic and rheological characterization. Phycol. Res. 2016, 64, 185-193. [CrossRef]

71. Cotas, J.; Figueirinha, A.; Pereira, L.; Batista, T. The effect of salinity on Fucus ceranoides (Ochrophyta, Phaeophyceae) in the Mondego River (Portugal). J. Oceanol. Limnol. 2019, 37, 881-891. [CrossRef]

72. Dettmar, P.W.; Strugala, V.; Craig Richardson, J. The key role alginates play in health. Food Hydrocoll. 2011, 25, 263-266. [CrossRef]

73. Viswanathan, S.; Nallamuthu, T. Extraction of Sodium alginate from selected seaweeds and their physiochemical and biochemical properties. Int. J. Innov. Res. Sci. Eng. Technol. 2014, 3, 10998-11003.

74. El-Manawy, I.; Nassar, M.; Rashedy, S. Spatial and temporal variations in the nutritional composition of some seaweeds from the Red Sea, Egypt. Egypt. J. Phycol. 2019, 20, 29-50. [CrossRef]

75. Chapman, V.J.; Chapman, D.J. Seaweeds and Their Uses; Springer: Dordrecht, The Netherlands, 1980; ISBN 978-94-009-5808-1. 